\title{
DEFERRAL OF SENTENCE: PRINCIPLES, PRACTICE AND PROPOSALS.
}

\author{
His Honour Judge David Smyth QC \\ INTRODUCTION
}

Some years ago, when those concerned with the sentencing of offenders in Northern Ireland were first attempting to get to grips with what exactly was involved in the concept of "restorative justice", it occurred to some of us that the principles of "restorative justice" were not limited to diverting offenders from the courts. Properly understood and applied these principles could, at the later stage of sentencing, be used either to divert offenders from custody or to give some bite to court orders that otherwise would have little direct impact on the offender, for example binding over and the various forms of discharge.

The extent to which existing formal sentencing powers recognise restorative aspects of justice are very limited. Compensation and community service orders have reparative elements which might be regarded as "restorative" but the manner of their imposition and the way in which these powers are enforced minimise the extent to which the offender is made responsible for "putting things right." 2

All sentencers in the United Kingdom have however possessed a discretionary power that has on occasions been used to effect a restorative resolution in sentencing: the power to defer passing sentence for the purpose of having regard to the offender's conduct after conviction. ${ }^{3}$ This is one of the few areas of sentencing that has remained unaltered by successive criminal justice measures. The suggestions made in this article result from a

1 "The term 'restorative justice' is a convenient shorthand expression that is commonly applied to a variety of practices which seek to respond to crime in a more constructive way than is conventionally achieved through the use of punishment At the risk of over-simplification, the philosophy on which it is based can most helpfully be summarised in terms of the "three Rs" of Responsibility, Restoration and Reintegration. One of the primary aims of most restorative justice approaches is to engage with offenders to try to bring home the consequences of their actions and an appreciation of the impact they have had on the victims of their offences. A second aim is to encourage and facilitate the provision of appropriate forms of reparation by offenders towards either their direct victims (provided they are agreeable) or the wider community. A third aim is to seek reconciliation between victim and offender where this can be achieved and, even in cases where this is not possible, to strive to reintegrate both victims and offenders within the community as a whole following the commission of an offence." For this definition see J. Dignan [1999] Crim.LR 48.

2 See, eg J. Dignan, "Repairing the Damage. Can Reparation be made to work in the service of Diversion?" (1992) 32 BJ Criminol 453.

3 Examples include not only financial compensation but work undertaken directly on behalf of victims and, in at least one instance, work done under supervision by an affected party in a case of arson(see later). Figures (discussed later in this article) suggest about $3 \%$ of all court disposals excluding fines are deferral orders. 
study undertaken in 1997 and 1998 to assess the extent to which Northern Irish courts used deferral and for what purposes.

What impressed most was the frequency with which our courts did defer passing sentence. Almost equally impressive was the extent to which the practice and approach of individual sentencers to deferral varied. Since the power is discretionary and since it has received relatively little attention in authoritative texts or in Superior Courts this is perhaps not that surprising. However the virtues of discretion would not be unduly fettered by suggestions as to what could be regarded as good practice.

What follows divides into three parts. In the first I attempt to outline the existing statutory framework and relevant case law in the three jurisdictions of the United Kingdom (Scotland, as will be seen, is very different). The second part gives some indication of the present use of deferral in Northern Ireland. In the final part some specific suggestions are made for widening the present powers in a way that would permit greater application of the principles of restorative justice ${ }^{4}$ and allow greater flexibility in relation to the treatment and rehabilitation of offenders suffering from drug addiction. ${ }^{5}$

\section{DEFERMENT OF SENTENCE: THE LEGISLATIVE FRAMEWORK IN NORTHERN IRELAND}

Article $3^{6}$ of the Criminal Justice (NI) Order 1996 provides:

"Subject to the provisions of this Article, the Crown Court or a magistrates court may defer passing sentence on an offender for the purpose of having regard, in determining his sentence, to his conduct after conviction (including where appropriate, the making by him of reparation for his offence) or to any change in his circumstances".

The Order places specific limitations on the exercise of the power. Only one period of deferral is permitted and that for a maximum of up to six months. ${ }^{7}$

4 The Review of Criminal Justice in Northern Ireland, which is due to be published in the course of this year, is likely to attach considerable attention to some forms of restorative justice. Review of Criminal Justice in Northern Ireland, a Consultation Paper NIO 1999. "In certain circumstances, restorative justice can offer a more inclusive approach to dealing with the effects of crime. It concentrates on restoring and repairing the relationship between the offender, the victim and the community at large. It can operate in a number of contexts, both within the formal prosecution process and outside it. It depends crucially on the offender admitting the wrong and showing some sign of wanting to put it right. In restorative schemes, where all parties consent, some form of victim-offender mediation may take place. This can be done directly, in a conference, or indirectly, through intermediaries. In recognition that the effect of crime goes beyond those initially involved, there is also scope to include family members and representatives of the wider community."

5 See developments in relation to the setting up of Drugs Courts, particularly in the United States, eg Hora, Schma and Rosenthal, (1999) 74 Notre Dame LR 439.

6 Formerly Article 11 of The Treatment of Offenders (NI) Order 1989.

7 In $R$ v Ingle [1974] 3 All ER 811, it was accepted that there was an inherent power to postpone sentence at the end of deferment but this inherent power should only be exercised where there were strong reasons for doing so. 
The offender must consent. The court must be satisfied that deferral is in the interests of justice. It may not, at the same time as deferring sentence, remand the offender. The court may, however, deal with the offender before the end of deferment if, during that time, he is convicted in Northern Ireland of any offence. This might appear to suggest that, with this exception, the court does not have power to sentence an offender before the deferral period has expired.

Deferment of sentence developed from the report of the Advisory Council on the Penal System (1970). ${ }^{8}$ Two types of appropriate cases were identified by Wootton: first, those where the court wished to confirm an offender's promise of good behaviour or await the outcome of a specific event such as a new job, and secondly, those where the offender had promised to make reparation. Despite Wootton recommending that in deferring sentence a court be given power to impose formal conditions, as was the case in Scotland, this proposal was not adopted in the legislation. This appears to have been due to an apprehension that there would be a risk of "double jeopardy", a person being sentenced twice for the same offence or, rather, receiving a greater sentence than he would have for the original offence. It also reflected concerns that difficulties might arise in determining whether specific conditions had been breached and the extent to which these breaches should be taken into account at final sentence. ${ }^{9}$ A Home Office memorandum which accompanied the Criminal Justice Act 1972 indicated that, notwithstanding the absence of a power to prescribe formal conditions, the court should record the specific object of the deferment and make this clear to the offender. The deferring court should also specify how it expected the sentencing court to be informed of progress. ${ }^{10}$

Since the introduction of the power to defer sentence in England and Wales there have been a number of case-law-based developments resulting from appeals from justices and Crown Court Recorders ${ }^{11}$. An obvious difficulty that was inevitably going to arise was what approach the court should take where there remained unresolved matters arising out of allegations in relation to behaviour during the period of deferment. These cannot be taken into account by the court considering whether the offender has conformed to the spirit of deferral ${ }^{12}$. To what extent can and should a court use the power to

8 Cmnd 4953.

9 It must be borne in mind that the power to defer sentence in England and Wales was going to be exercised by both stipendiary magistrates and lay justices assisted by legally qualified clerks and by Crown Court Recorders, many of whom are parttime, a much more disparate body than in Scotland, where the power is exercised principally by Sheriffs, and in Northern Ireland, where the power is exercised by Resident Magistrates, of whom there are now 17 and County Court judges sitting in the Crown Court of whom there are now 14.

$10 R$ v Gurney [1974] Crim LR 472.

11 The same court which deferred sentence should determine final sentence: $R$ v Ryan [1976] Crim LR 508. Similarly, the same counsel should appear at final sentence as at the deferral.

${ }^{12} R$ v Aquilina [1990] Crim LR 134, where the court held that unresolved matters should not affect the outcome in any way. Quaere whether there could be a short adjournment to permit such outstanding issues to be resolved; $R$ v Ingle [1974] 3 All ER 811, where the court accepted that adjournment was possible but the practice was discouraged. Clearly the court is concerned to prevent judicial 
adjourn in order to permit such matters to be resolved? This remains one of the difficulties encountered in deferring sentence. Proceedings for breach of the probation order can, by contrast, be brought after the period of the order has run its course. On the other hand there can be both excessive delay in bringing breach proceedings and erratic and inconsistent approaches to such proceedings. These of course have their own "double jeopardy" aspect.

The Courts have also given guidance as to what the approach of the sentencing court should be where there is clearly an expectation that a custodial sentence will not be imposed. ${ }^{13}$ The English Court of Appeal has also considered the extent to which conditions could be attached to deferral orders. In an unreported case the trial judge had imposed a number of conditions designed constructively to control the way the accused, a woman, behaved. Since he appeared to be assuming powers to impose conditions, the matter was brought back before him. He removed the conditions but indicated that if the accused did not behave in a way that reflected those conditions this factor would be taken into account at sentencing. Whilst the Court noted the complaint about conditions there was no criticism of the deferment and the implied conditions on the basis that the judge was deferring sentence to see how the defendant would settle down to new responsibilities, in this case as mother of a child. The Court shortened the probation order imposed at the end of the deferral. ${ }^{14}$

The most detailed Court of Appeal guidance on the use of deferment was set out in $R$ v George. ${ }^{15}$ The sentencing court should make it clear to the defendant what the purpose of the deferment is and what is expected of him:

prevarication, a matter of additional concern under the Human Rights Act; $R \mathrm{v}$ Anderson [1984] 78 Crim App Rep 251 where a case was mistakenly listed seven months after deferral. It was held that jurisdiction was not lost for delay caused by the mistake. The trial judge was on other duties and the court clerk relisted the case for his return in the mistaken belief that the original judge had reserved the case to himself. If, during the extra month, the offender had committed an offence it obviously could not be taken into account

13 In $R$ v Gilby [1975] 2 All ER 745, where magistrates committed to the Crown Court for sentence after deferral, the court disapproved, expressing a general caution: "Exercise of the power for purposes other than the prescribed purposes in the Act is an invalid exercise of the power and can lead to great difficulty." Where an offender's report and/or his change in circumstances are not unfavourable a substantial custodial sentence is not appropriate. See also $R$ v Head [1976] 63 Crim App Rep 157 where it was made clear that whilst this may not amount to a rule of law, the principle was clear. $R$ v George [1984] $79 \mathrm{Cr}$ App Rep 26 and $R$ v Dray [1991] 92 Cr App Rep 305. If an offender has substantially conformed, or attempted to conform with the expectations of the court he is entitled to expect that an immediate custodial sentence will not be imposed. Also $R$ v Fairhead [1973] 2 All ER 737. The court should always ask the defendant if he consents to deferral. Where the court decides to use its common law powers to delay passing sentence it should avoid the use of the words "deferred sentence" (see page $741 \mathrm{e}, \mathrm{f}$ and $742 \mathrm{~d}$ ). There can only be an appeal against sentence when that is finally passed but the Attorney General can refer a deferral order on the basis that it is unduly lenient at the time of deferral. Attorney General's Reference No. 22 of 1992.

14 See $R$ v Mumford, Court of Appeal, Criminal Division, 26 July 1991. Transcript on Lexis.

$15 R$ v George [1984] 3 All ER 13. 
"what he is expected to do or refrain from doing". Before selecting deferral the court should carefully consider whether it would be more appropriate to use one of the other means available of dealing with the offender. A note should be made of the purpose, and ideally the defendant should be give notice in writing. When finally passing sentence the court must determine if the defendant "has substantially conformed or attempted to conform with the proper expectations of the deferring court." If he has, he may legitimately expect not to be sentenced to immediate custody at the end of the deferred period. If he has not, the court should state in what respects he has failed.

The Court touched on reparation: "It will, one imagines, seldom be in the interests of justice to stipulate that the conduct required is reparation by the defendant"16, but the Lord Chief Justice went on to consider those situations where deferment will be more appropriate than, for instance, a probation order:

"where the defendant is to make a real effort to find work, or where the sentencer wishes to see whether a change in the defendant's attitude and circumstances, which appears to be a possibility at the time of deferment, does in fact come about. Again, deferment may be the appropriate course where the steps to be taken by the defendant could not of their nature be the subject of a condition, for example where he is to make reparation, or at least demonstrate a real intention and capacity to do so." 17

There appears to be some ambiguity in the courts' interpretation of the use of deferment to facilitate reparation. Whilst it is specifically mentioned in the legislation the courts are reluctant to be seen giving an opportunity to an offender to "buy his way out" of a certain sentence. The Court of Appeal recognised that reparation may be appropriate but thought it would seldom be appropriate to stipulate its requirement. Obviously while a condition of reparation cannot be attached to a probation order, specific compensation and restitution orders can now be made in addition to other court orders.

The Wootton Report had considered this situation: "Deferment of sentence with a condition of reparation would, we think, be more appropriate where the offender undertook to make reparation but the court was uncertain about his determination to do so either then or in the immediate future." The Department of Social Policy and Social Work at the University of York, who conducted research into the use of deferment (see below), suggested that deferment could be used more often for the purpose of reparation, even suggesting a pilot scheme which would permit deferment to be used more systematically.

In a recent Scottish case ${ }^{18}$ the Sheriff deferred sentence for a year in a case of theft for the offender to be of good behaviour and to bring $£ 300$ to the court. After a year, he had saved $£ 180$. The case was further deferred and by the time it was called again, the offender had spent the $£ 180$ and was sentenced to imprisonment. On appeal the High Court held that the Sheriff was not to

16 Ibid $\mathrm{p} 15$ a.

17 Ibid $\mathrm{p} 15 \mathrm{~h}$.

$18 R$ v Cameron and Webster [1997] SCCR 228. 
be commended. If he had considered a compensation order to be appropriate he should have made it at the time.

Leaving aside this apparent ambiguity over reparation as a specific stipulation by the Court on deferring sentence (perhaps remarkable given that this was an important consideration of the Advisory Council which recommended the introduction of deferral and is also incorporated into the legislation), the direct imposition of formal conditions upon an offender as part of a deferral order is without statutory basis. It does however seem that the courts are prepared to contemplate that expectations as to conduct and behaviour can be agreed. This seems clear from both $R \mathrm{v}$ Mumford and $R \mathrm{v}$ George.

If the offender by way of mitigation and with the encouragement of the court "sets up his stall" by committing himself to a course of action (whether that be to undergo voluntary restrictions, submit to supervision, make restitution or some form of reparation, undertake some form of community work or take a therapeutic course of treatment for alcohol or drug addiction, not reside in a certain area, take up employment, stay away from drug dealing locations or known criminals) and if the court indicates to the offender that successful performance of these undertakings will result in significant mitigation of the commensurate sentence (with that stated in court) then presumably neither the letter nor the spirit of Article 3 has been offended?

It certainly seems from our brief research into the use of deferral in Northern Ireland that many judges and most magistrates are deferring sentence on this basis, that is, that expectations can be agreed between court and offender and the offender has a clear expectation that, if he meets these expectations, a custodial sentence will be avoided or a lesser penalty imposed. The risk of "double jeopardy" is avoided by the sentencing court stating what the commensurate sentence is at the time it defers.

\section{THE POSITION IN SCOTLAND}

In Scotland, where deferred sentences are used more frequently ${ }^{19}$ and where the suspended sentence is unknown, there are no such uncertainties. The statutory basis is as follows:

"For the avoidance of doubt it is hereby declared that it is competent for any Scottish court to defer sentence after conviction for a period of such conditions as the court may determine". ${ }^{20}$

19 Deferred sentences constitute $6.4 \%$ of disposals of charges proved. This compares with probation orders, $1.8 \%$, and community service, $1.9 \%$. The suspended sentence is unknown to Scots Law, see: Nicolson, Deferment of Sentences in Scotland [1993] Scots Law Times.

20 S. 47 of the Criminal Justice (Scotland) Act 1963. Further statutory provisions are contained in the Criminal Justice (Scotland) Act 1979 ss 219 and 432 and the Criminal Justice (Scotland) Act 1980 where sections 53 and 58 permit the imposition of probation and compensation orders following a deferred sentence. They have the same provision which permits sentence to be brought forward in the event of the commission of another criminal offence. 
Scotland therefore has a much more flexible scheme which gives sentencers very wide discretion and which enables them to sentence in accordance with the facts as they appear to be at the end of the deferral period but with all the rights of sentencing at first instance. There is no "once and for all" limitation and no six months limit. The power to impose conditions is expressly conferred and in terms that give wide discretion.

Periods of deferral imposed vary from up to 25 weeks (well over 50\%) to 35 weeks and one year (used less frequently but favoured by Scottish High Court Judges). Extensions are frequently imposed. These have the effect of increasing the average length of deferral to 30 weeks from 25.

While the Scottish system gives greater flexibility it is also subject to considerable differences in the way it is applied by individual Sheriffs. Practice varies considerably from court to court as to what is said by the Sheriff when sentence is deferred and as to what standard is applied by the court when assessing compliance with conditions. This is so even with the most basic condition "to be of good behaviour". Deferral is used for a wide variety of cases including (though less frequently) some of the more serious. Most typically the power to defer is used in respect of infrequent offenders to permit them to show they have acted out of character in specific cases to achieve a direct object, for example, to see if employment is taken up and kept and also in cases of last resort to permit persistent offenders the opportunity to prove they can alter their lifestyle or break a pattern of offending.

The Scots have encountered similar problems to those experienced in England and Wales. How does one fit the deferral of a sentence and the ultimate sentence of the court into a tariff system? This in practice may not be such a problem since deferral is unlikely to be used for the more typical tariff offence unless there is a very cogent reason for doing so.

The difficulty of ensuring that there is continuity of the sentencing court (both sentencer and counsel) has arisen. There are both administrative and practical problems. These in a busy court can easily be imagined. An effective and accurate record must be made and retained. The volume of cases for a busy Sheriff and the number of times when, for unavoidable reasons, another judge has to pass the ultimate sentence make this essential. This is not always achieved.

The requirement to give a full explanation at the time of deferral as to what is expected and as to what is likely to happen requires both care and consistency. In Northern Ireland this is of even greater importance since the offender is required to consent. Extensions occur frequently in Scotland (in $43 \%$ of cases). This contrasts with the rigidity of our once and for all six month's limit. In Scotland there is more scope for prolixity and for greater frequency of court appearances with consequent cost in time and court resources. Of the reasons for extensions being granted $27 \%$ were because the court wished to extend the period of deferral for specific reasons, $20 \%$ were because of the availability of reports, $14 \%$ were to enable the same Sheriff to appear and $30 \%$ were because the offender failed to appear!

There can be difficulty in determining whether an offender is in breach of a condition especially if the condition is not specific. The following are examples of specific positive conditions, which have been imposed by courts 
in Scotland: restitution or some form of reparation; completing therapeutic courses; saving towards compensation or financial penalty; the completion of a course of education or training course; and the taking up and keeping of employment. Negative conditions imposed by Scottish courts have included such matters as: restrictions on driving and exclusion from certain areas. The Nicholson research was conducted prior to 1992 and the picture may have altered since that date but no further research has been done on the use of deferred sentence in the United Kingdom since that date. ${ }^{21}$

\section{DEFERRAL OF SENTENCE IN NORTHERN IRELAND}

To what extent do sentencers in Northern Ireland use deferral, in what circumstances and what do they seek to achieve by its use? There are few statistics available which is not perhaps a matter of surprise since an order for deferral of sentence is not a final disposal. There are some however.

In 1996 the Northern Ireland Court Service did publish a figure for the number of deferral orders in adult business in Northern Ireland's magistrates courts. Of a total of 31,387 disposals (excluding fines), 1353 were deferrals (or $4 \%$ of the total). By contrast 1492 probation orders were made $(5 \%)$. In itself this demonstrates not just frequency of use but, given the fundamental position of probation in sentencing, the significance of deferral as a sentencing measure for magistrates. ${ }^{22}$ There are no comparable figures for either juvenile court disposals or for the use of deferral in Crown Courts. The last published figure for juvenile disposals which include a total for deferrals was for 1994 when resident magistrates deferred on 94 orders (out of a total of 3086 , about $3 \%$. This compared with 470 probation orders, $15 \%$. $)^{23}$

The genesis for this article was concern about the extent of use of deferral and, in an attempt to find out more, in 1997 with the assistance of the Criminal Justice section of the Northern Ireland Office questionnaires were distributed to all county court judges and resident magistrates in Northern Ireland as well as a number of probation officers. Twenty three of a total of thirty, the complement at the time, replied. (11 judges and 12 magistrates). The purpose was to determine how sentencers regarded existing powers to defer sentence and whether there was any scope for change.

Over half $(60 \%)$ of the judges who replied to the survey estimated that they had deferred sentences on fewer than five occasions in the preceding 12

21 The following suggestions were made to improve the efficiency of deferment of sentence in Scotland after research commissioned by the Scottish Office in 1992 "The Deferred Sentence in Scotland, Nicholson, 1992): the introduction of a standard reminder letter for issue to offenders shortly before the date of their final hearing; where possible, the desirability of achieving continuity of sentencer from initial to final hearing should be achieved; a standard procedure should be introduced for recording the views of the initial sentencing court for the benefit of the court or final sentence and for any substantial appeal court; a study should be made to identify the cause of and reduce the frequency of unplanned extensions to deferments; consideration should be given to the introduction of a consistent and effective method of alerting the offender to precisely what is expected during deferment; central government should establish a system of routine collection and publication of statistics on the use and practice of deferring sentence.

22 Judicial statistics 1996: N.I. Court Service, Belfast.

23 Judicial statistics 1994: A Commentary, N.I. Court Service, Belfast. 
months compared with only $8 \%$ of magistrates. Since most offences that come before the Magistrates' Court are less serious than those tried before a judge, it is understandable that the practice of deferral is much more prevalent amongst the magistracy, with three-quarters having used it more than ten times in the past year compared with $30 \%$ of judges.

As regards eventual outcome three-quarters of those who deferred sentence reported that in very few cases (fewer than 15\%) did a custodial sentence follow a period of deferment. In total three-quarters of judges and two-thirds of magistrates stated that in very few cases did they take the course of imposing a custodial sentence. Mirroring this, most respondents (83\%) also reported that in the majority of their cases, defendants substantially fulfilled the expectations of the Court.

The reason cited most often for deferring a sentence (referred to by twothirds of respondents) was to permit the offender an opportunity to take part in a rehabilitative or therapeutic programme (Table 1). The next most popular conditions attached to a deferred sentence involved the payment of compensation or maintaining voluntary contact with the probation service.

\section{Table 1}

\begin{tabular}{|ll|}
\hline Case Deferred to Permit & Number Citing \\
Compensation & 19 \\
Voluntary contact with Probation & 19 \\
Rehabilitation/therapeutic programme & 20 \\
Reparation in other form & $5^{*}$ \\
Residence requirement & 6 \\
Voluntary work in community & 10 \\
\hline
\end{tabular}

* This figure includes examples not only of financial reparation but other forms of "restorative action" by offenders including work done for victims who had suffered from arson attack (sectarian). Deferral has also been used with the consent of victim and offender to facilitate meeting and apology and payment of compensation in criminal damage cases. My own view is that there are some cases where this approach is merited but they have to be carefully selected.

Without exception, respondents felt that the power to defer sentence was useful, with $62 \%$ believing it to be very useful. Judges and magistrates were slightly less enthusiastic but over half of each $(55 \%)$ also believed it was very useful to defer sentences.

The most common advantage of deferring sentence, identified by $80 \%$ of respondents, was that this practice allowed offenders an opportunity to change. Just over a third (36\%) also believed that it was advantageous as it allowed the offender an opportunity to make some kind of reparation. In some cases the reparation was seen as necessarily involving the victim.

The judges' responses tended to concentrate on the type of offender best suited to a deferred sentence. Most felt that the power to defer was best 
employed where the crime did not correspond with their impression of the offender and that therefore they required more time to assess the case. Particular reference was made to offenders 'on the fringes of criminality' and those who would benefit from being removed from 'the adverse influence of others'. The circumstances in which deferral was considered to be useful ranged from serious crimes committed by young offenders to cases where disputes had arisen within the family or other similar situations.

The magistrates put more emphasis on their expectations of the offender. A number said that they made it clear to the defendant that this was their last chance before custody - one voicing the possibility that six months out of trouble may foreshadow a lifetime out of trouble. As one put it, "your future is now put to the test and in your hands". One considered deferral to be a more effective course of action than a suspended sentence as it did not have the same sense of finality. Another reflected the views of many in stating that a sentencer can use "initiative and judgement towards reform and rehabilitation rather than punishment per se". Only one mentioned that the period of deferral allowed time for 'victim awareness.'

The comments of probation officers referred largely to the effect of the deferral on the offender and the role of probation in his disposal. The knowledge that the offender must return to court 'concentrates the mind' and provides reinforcement of probation's efforts with a defendant. Goals can be easily defined, which encourages responsibility and motivation in the defendant.

The range of advantages and disadvantages referred to by respondents are set out in Tables 2 and 3 below.

\section{Table 2}

\begin{tabular}{|ll|}
\hline Advantage & Number Citing \\
Opportunity to change & 22 \\
Opportunity to make reparation & 9 \\
Public perception & 1 \\
Alternative disposal & 7 \\
Time to reflect & 5 \\
Keep people away from others & 1 \\
Time to get help for drink/drugs & 2 \\
Facilitates a better understanding of & 1 \\
victim
\end{tabular}

\section{Table 3}

\begin{tabular}{|ll|}
\hline Disadvantage & Number Citing \\
Perception of lightness & 8 \\
Opportunity to re-offend & 14 \\
No formal constraint & 13 \\
\hline
\end{tabular}




\begin{tabular}{|ll|}
\hline Timescale short & 4 \\
Administrative & 5 \\
Increased time between offence and & 8 \\
sentence & 1 \\
Probation reluctance & 2 \\
No use for addicts: drugs/drink & \\
\hline
\end{tabular}

The most commonly cited disadvantage with deferring a sentence (Table 3) was the opportunity it afforded an offender to re-offend, with half of all respondents referring to this. A similar proportion were also concerned that no formal constraint could be imposed. While offenders could be given a deferred sentence and asked to attend specific therapies, avoid 'bad' company or make some kind of restitution, these 'requests' had no formal status. Offenders were not required to follow courses identified by the courts at the time of their deferment of sentence.

Many respondents felt that the administration of deferred sentences was poorly defined. Problems were identified where an offender was accused of, but denied, other offences during this period of deferral. A lack of monitoring and inadequate systems for dealing with breach complicated the process. Some felt that deferral actually limited their sentencing options, stating that it was not easy to impose a custodial sentence once the six months was up. In certain cases, the final imposition of a custodial sentence may be open to challenge if the sentencer has previously indicated that good behaviour may be grounds for leniency.

A number of magistrates expressed concern about the degree of subjectivity that deferrals required of them. One described having to infer "declared intention to reform without any concrete evidence of real intention to reform". Others suggested that the system risked compromising fairness. One warned of losing control over the process, citing a "risk of a loss of uniformity in ultimate disposal" and referring to "the growth of a complicated body of law on the subject which will negate the original intention." Another saw complications arising where the ultimate sentence was based on both the original offence on a tariff and the defendant's conduct in the interim, particularly where he has not complied with conditions. One probation officer expressed concern that very minor offences may constitute a breach and result in custody. There was also some concern that ancillary orders such as disqualifications or seizure orders could not be made pending the determination of the entire sentence.

Again, one mention was made of the victim, who suggested that "victims might feel more vulnerable and in a sense betrayed" if the offender is not sentenced immediately.

Despite identifying these disadvantages most respondents $(56 \%)$ did not feel restricted by the lack of a statutory power to impose positive conditions on those receiving deferred sentences, not least because, according to one magistrate, "implied conditions" are already being imposed.

More than two-thirds (70\%) of all respondents thought that there was scope for greater use of deferred sentencing, as this would lead to greater 
sentencing power. However, there was some resistance to this: one-third of judges and one-third of magistrates agreed that there was no scope for widening use of deferred sentencing.

One judge foresaw the same "problems of articulation and effect" as exist now, while some magistrates and probation officers were concerned about the issue of compliance. One magistrate stated that greater powers to defer would necessitate an "objective test of compliance" because requirements were not uniformly verifiable - "How does one determine that an offender hasn't breached negative conditions?" A probation officer saw further problems where a defendant had not re-offended but had failed to meet the express conditions or where particularly difficult conditions had been imposed, such as remaining drug-free.

Probation officers pointed out that imposing conditions created problems, particularly where more than one condition was being imposed. There was also a need to consider how conditions could be made "commensurate with civil rights."

The power to defer sentences was seen as potentially useful in those instances where the offender lacked awareness of the full nature of his crime, or where the crime was alcohol induced. This latter circumstance, the role of alcohol in the crime, was the one most referred to (by $70 \%$ of those answering this section). ${ }^{24}$

\section{ENSURING GOOD PRACTICE?}

In the light of the above what improvements could be made to ensure that deferral of sentence is used in the most effective manner that is consistent with principle? Recognition and application of what constitutes good practice would ensure that many of the concerns outlined above are met. I venture to list some of these here. I however feel that there is a reasonably good case to be made for changes in the enabling legislation. I therefore suggest some modest changes which would have the effect of clarifying areas where there are existing ambiguities and which would also give judges wider scope in using deferral.

Sentence should only be deferred where the court has good reason to suppose that deferment will influence the offender's future conduct. This is to state the obvious but it bears restating. Once the court has determined this the question of consent has to be addressed. In this context the precise expectations upon which passing of sentence may be deferred must be clearly stated and agreed with the offender before he is asked to give his formal consent. The offender should be asked to acknowledge these in court when he gives his consent. All expectations agreed with the court should be reduced to writing and a copy provided for the offender. At all stages it should be made clear that the offender's consent is required. Care should be taken by the court to ensure that the purpose of deferral is clearly expressed including the provision to the offender of the opportunity to avoid custody or to mitigate his punishment. It should be made clear, in the event of re-

24 I would like to acknowledge the assistance given to me in the collation of these questionnaires by Tom Haire of the Northern Ireland Office and also the assistance of David McKeown also of the NIO, Criminal Justice Division. 
offending or failure to meet conditions or expectations agreed with the court, that no greater penalty will be imposed than that stated by the court to be commensurate with the offence committed. The same judge should pass final sentence as first ordered deferment (with obvious savings).

These proposals would ensure better uniformity of practice and permit closer monitoring. They would meet most of the concerns raised by the Court of Appeal in $R$ v George and would make it clear that a person who has had the passing of sentence upon him deferred will not be at risk of a greater penalty as a result of his failing to meet conditions or expectations. A written set of conditions would assist the court in assessing compliance with the spirit of deferral and with the difficult task of deciding what to do in the event of default.

Where precise decisions have been breached the offender can perhaps be returned to the court and dealt with early. Overall this would assist the offender to know what is expected of him. The court's discretion would still remain wide particularly in relation to more subjective conditions or exhortatory expectations. Not only would this more formal approach substantially widen the opportunity given to the court to influence the offender's behaviour by giving it a framework within which the offender has an incentive but it also clearly places the responsibility for achieving this on the offender. However in my view much more could be achieved by the following amendments to the existing law.

\section{LEGISLATIVE CHANGE}

\section{Proposed Amendments To Article 3 of The Criminal Justice (NI) Order 1996}

The text of the relevant parts of the current law are reproduced here with the proposed amendments in italics:

"Deferment of sentence

3 (i) Subject to the provisions of this Article, the Crown Court or a magistrates' court may defer passing sentence on an offender after conviction for a period and on such conditions as the court may determine for the purpose of enabling the court to have regard in determining his sentence to his conduct after conviction (including, where appropriate, the making by him of reparation for his offence) or to any changes in his circumstances or lifestyle.

(ii) Any deferment under this Article shall be until such date as may be specified by the court, not being more than 6 months after the date on which the deferment is announced by the court and where the passing of sentence has been deferred under this Article it shall not be further deferred thereunder unless the court is satisfied that special circumstances exist and it would be in the interests of justice to further exercise the power in accordance with the provisions of paragraph (3) and, in any event, such date shall not be more than 12 months after the date on which deferment was first announced by the court.

(iii) The power conferred by this Article shall be exercised only if the offender consents and the court is satisfied having regard to the nature of the 
offence and the character and circumstances of the offender that it would be in the interests of justice to exercise the power.

(iv) A court which under this Article has deferred passing sentence on an offender may pass sentence on him before the expiration of the period of deferment if during that period he is convicted in Northern Ireland of any offence or if the court is satisfied that the offender has breached a condition imposed by the court.

\section{Amendment No 1}

"for a period and on such conditions as the court may determine"

This would provide a statutory basis permitting the enforcement of agreed conditions; a Consent remains essential but the court order can record conditions and ultimately a sanction can be imposed if these agreed conditions are not met. This would be in line with the original recommendation of the Advisory Council on the Penal System (Wootton Report 1970). It would not be as far reaching as the Scottish provisions whereby the court is simply empowered to "defer sentence after conviction for a period and on such conditions as the court may determine". (Section 47 of the Criminal Justice (Scotland) Act 1963). The restrictions currently imposed by our Article 3 would remain unchanged. However no limit is imposed on the conditions which may be attached to the Order deferring sentence.

\section{Amendment No 2}

"and lifestyle"

This would further define "any change in his circumstances" as to make it clear that the ambit of deferral is not simply confined to such matters as the obtaining of a job and so forth but would also include the successful completion of medical treatment and detoxification of an offender dependent on drugs or alcohol.

\section{Amendment No 3}

"unless the court is satisfied that special circumstances exist and that it would be in the interests of justice to further exercise the power in accordance with the provisions of paragraph (3) and in any event such date shall not be more than 12 months after the date on which deferment was first announced by the court".

This would permit the court to extend a deferral where special circumstances are found to exist. It is designed to meet those cases where, unusually, a further period of deferral is appropriate, for example where there is an unresolved allegation of the committal of an offence within the first deferral or where a course of medical treatment has still to be completed and reported upon or where an academic year is uncompleted at the end of the first deferral period. 


\section{Amendment No 4}

"or if the court is satisfied that the offender has breached a condition imposed by the court".

This would permit earlier resolution of a case where an offender has clearly demonstrated no intention to observe the terms of the deferral and its purpose. This would meet a concern expressed by some probation officers and would increase the discretion available to the court. It may be criticised on the basis that it emphasises the compulsory and non-voluntary aspect of deferment but the incentive an offender has to avoid custody does provide motivation and this option might not be available without the offender's agreement to submit to conditions, (for example there would be little point in a court having to wait six months before sentencing an offender who has not observed a condition of contact with a probation officer or of residence or of undertaking treatment or of engaging in agreed restorative actions).

These amendments in themselves do no involve too radical an alteration to the existing scheme of the Article. To an extent they recognise what sentencers have been attempting to achieve with the existing power. They remove some uncertainties and clarify some ambiguities but they also significantly widen the discretion available to judges and would give clear statutory authority to what is already being achieved by individual sentencers on the basis of expectations agreed between the offender and the court.

The benefits of giving these further powers to sentencers go beyond the matters discussed above. The Scots and the French use their powers to encourage restitution or some form of reparation in kind. As the concept of restorative justice develops the principles involved in restoring the relationships between offender, victim and community can be accommodated within this statutory framework.

These wider powers could be used to encourage the completion of therapeutic and detoxification courses. They could facilitate the completion of training and education; the taking up and keeping of employment; the monitoring of behaviour. Such matters as saving towards making financial compensation to victims, direct contract with victims through mediation or group conferencing schemes could well fit within this framework. Deferment could permit voluntary work to be undertaken by offenders whose needs are not met by community service schemes and also would permit less formal contact with probation officers, other trained facilitators and, in appropriate cases, the police.

Perhaps more ambitiously these enhanced powers could be particularly useful in cases where offenders are subject to opiate addiction, (a problem in parts of Northern Ireland that has recently shown signs of becoming as acute as it has elsewhere in the world). Whilst in the recent Criminal Justice (NI) Order $1998^{25}$ provision is made for drug testing and treatment orders it is

25 These are "stand alone Orders" introduced by the Criminal Justice (NI) Order 1998 Articles 8-11. These provisions, which have not yet come into force, provide for: a new order to be made by a criminal court with the consent of the offender; requiring the offender to undergo drug rehabilitation treatment; the court would be expected to review the offender's progress regularly; the offender would be 
very unlikely that these provisions will be brought into force in the medium term.. No funding has been planned by the Department of Health and Social Services and no facilities or protocols exist within the local health service that would meet the demands of compulsory treatment and testing orders made by the courts. Failing such compulsory measures being introduced (and all the bureaucracy associated with these) the power to defer sentence to permit treatment and detoxification could meet some of the concerns intended to be met by formal treatment and testing orders. Deferral of sentence for the purpose of monitoring a course of treatment for opiate addiction or alcohol addiction and its outcome-result would be within the general scope of the power. It would involve the court in a much more direct way with the health service than has been the case up to the present. There are however many indications already as to the benefits of such a closer relationship. ${ }^{26}$

required to submit to weekly drug screening tests; offenders could be brought before the court for failure to comply. Comment: This seems to be an over elaborate and resource intensive form of order particularly as, from January 1998, the Northern Ireland courts have had powers to make orders requiring offenders to submit to treatment to reduce drug and alcohol dependency on foot of probation orders.

26 In Dublin a "drugs court" is in the course of being established. Its jurisdiction will be exercised by District Judges utilising existing powers. Other schemes are in existence in Australia (Sydney), Canada and in the United States, eg The Miami Drug Court discussed by Hora, Schma and Rosenthal, Notre Dame Law Review, op cit $\mathrm{n} 5$. 